\title{
Inheritance of the Flower Types of Gerbera hybrida
}

\author{
Wesley E. Kloos', Carol G. George ${ }^{2}$, and Laurie K. Sorge ${ }^{3}$ \\ Department of Genetics, North Carolina State University, Raleigh, NC 27695-7614
}

ADDITIONAL INDEX WORDS. capitulum traits, floret traits, gerbera genetics, crested gerberas, spider gerberas

\begin{abstract}
Cultivated gerbera daisies [Gerbera hybrida (G. jamesonii Bolus ex Adlam $\times$ G. viridifolia Schultz-Bip)] have several different flower types. They include single and crested cultivars that have normal florets with elliptical (ligulate) outer corolla lips and spider cultivars that have florets with laciniated (split) outer corolla lips appearing as several pointed lobes. The objective of this investigation was to determine the mode of inheritance of the major flower types of gerberas in the North Carolina State Univ. collection. The collection contained parents and four generations of progeny representing a wide range of single and crested cultivars and some spider cultivars. Genotypes of parents used in crosses were determined by testcrosses to single-flowered, ligulate floret cultivars similar in phenotype to the wild, parental gerbera species. Testcrosses indicated that the wild type was recessive to the crested and spider flower types and given the genotype crcrspsp. For each of the types, a series of crosses were made to produce $\mathbf{P}_{\mathrm{A}}, \mathbf{P}_{\mathrm{B}}, \mathbf{F}_{1}, \mathbf{F}_{2}, \mathbf{B C}_{1 \mathrm{~A}}$, and $\mathrm{BC}_{1 \mathrm{~B}}$ progeny. Allelism was tested operationally by crossing genotypes in all possible combinations and observing single-gene-pair ratios. Linkage relationships among the crested and spider loci were tested using dihybrid crosses and testcrosses. Phenotypic segregation ratios suggested the presence of two dominant alleles, $\boldsymbol{C r}$ and $\boldsymbol{C r}$, determining the enlarged disk and trans floret, male-sterile and enlarged trans floret, male-fertile crested types, respectively, and an unlinked dominant gene, $S p$, determining the spider type. Dominance appeared to be incomplete due to the reduction of trans floret length in most $\mathrm{Cr}^{d} \mathrm{cr}$ and $\mathrm{Crcr}$ heterozygotes compared to crested homozygotes and the appearance of the quasi-spider type (spider trans and disk florets and ligulate and/or slightly notched ray florets) among certain crested Spsp heterozygotes.
\end{abstract}

Cultivated ornamental gerberas are given the provisional designation Gerbera hybrida (Asteraceae) and are diploids resulting from crosses of G. jamesonii × G. viridifolia (Bremer, 1994; Hansen, 1999). They are among the most important cut and pot flowers marketed worldwide and have been produced commercially in Europe since the turn of the 20th century (Rogers and Tjia, 1990). Much of the breeding and cultivar development has taken place in the Netherlands, Denmark, France, Germany, Japan, and Israel. Commercial production began in North America in the early 1920s largely through the efforts of C.J. Van Bourgondien, Sr. who originally secured seeds from Europe (Rebhan, 1951). Extensive breeding at the Univ. of California at Davis during the 1970s led to the development of gerberas suitable for the garden (Harding et al., 1981). Later, breeders in Florida and California developed families of cultivars for cut flower production and pot flower production (Rogers and Tjia, 1990).

The early wild-type cultivars had daisy-like flowers with a composite inflorescence (capitulum) composed of one to three whorls of ray florets and several whorls of very short, inconspicuous trans and disk florets. According to the terminology of Drennan et al. (1986), based on the Univ. of California Davis G. hybrida population, disk florets are very small $(1.6 \pm 0.2 \mathrm{~cm}$ length), produce stamens, and have two corolla internal lips that are almost as large as the outer corolla lip, whereas ray florets are relatively large $(6.1 \pm 0.8 \mathrm{~cm}$ length), produce pistils, and have a large outer corolla lip (ligule) and two rudimentary corolla internal

Received for publication 20 May 2004. Accepted for publication 29 Aug. 2004. The authors thank Matthew Lemons, Cecil Tarrant, and Lyla Kloos for their technical assistance and Brooks Johnson, Felix Jones, and R. Garry Stephenson for use of their land for growing plants in the field. This study was funded by the North Carolina Agricultural Research Service (Project No. NCO6594). The use of trade names in this publication does not imply endorsement by the NCARS of the products named, nor criticism of similar ones not mentioned.

'Professor, to whom reprint requests should be addressed. E-mail: wesley_ kloos@ncsu.edu

${ }^{2}$ Research Technician.

${ }^{3}$ Visiting Scholar. lips. Ray florets are arranged marginally around the central disk florets. Transition (trans) florets are positioned between the outer ray florets and central disk florets and have a ligule much shorter than that of ray florets. Flowers exhibiting more than one whorl of ray florets have been referred to as the duplex type (Rogers and Tjia, 1990). Herein the term whorl refers to the spiral row of florets arranged about the axis of the mature capitulum and not the floral whorls 1 through 4 of the flower primordia (Yu et al., 1999). With the cultivation of large numbers of segregating progenies, breeders began observing variants of the wild-type flower. Some of the variants were quite attractive and included double (large-crested) and semi-double (semi-crested) flower and spider (laciniated) petal types. Over the past 20 years the crested trait has been introduced into many of the commercial gerbera lines (Rogers and Tija, 1990). The crested flower types were characterized by the addition of whorls of enlarged trans florets. These florets were variable in size and produced pistils. More recently, Helariutta et al. (1995) and Yu et al. (1999) made extensive morphological examinations of gerbera florets and found that ray and trans florets had nonfunctional staminodes, in addition to carpels (pistils), and disc (disk) florets were hermaphroditic, though functionally male. These investigators considered the inconspicuous pistillate florets located between the inner disk florets and outer ray florets of wild-type flowers to be a type of trans floret, though they were previously regarded as one of the types of disk florets (Rogers and Tjia, 1990). Many other ornamental plant species have cultivars exhibiting double and semi-double flowers that are highly valued by horticulturists (Reynolds and Tampion, 1983). Some of those that have been studied extensively include the white campion [Silene latifolia Poiret (Caryophyllaceae)] (Scutt et al., 1999), carnation [Dianthus caryophyllus L. (Caryophyllaceae)] (Scovel et al., 1998), chrysanthemum [Dendranthema $\times$ grandiflorum (Ramat.) Kitam. (Asteraceae)] (De Jong and Drennan, 1984), geranium [Pelargonium hortorum L. Bailey (Geraniaceae)] (Almouslem and Tilney-Basset, 1989; Nugent and Snyder, 1967), petunia [Petunia hybrida Hort. Vilm. (Solanaceae)] (Natarella and Sink, 1971; 
Van der Krol and Chua, 1993), snapdragon [Antirrhinum majus L. (Scrophulariaceae)] (Bradley et al., 1993; Stubbe, 1966), and sunflower [Helianthus annuus L. (Asteraceae)] (Fick, 1976). In the gerbera, the appearance and extent of flower doubleness is largely determined by the length of conspicuous trans florets in the capitulum, in the chrysanthemum, by the proportion of ray florets to disk florets in the capitulum, and in H. annuus, by the length of ligulate disk florets in the capitulum. In flowers of a family other than Asteraceae, flower doubleness is related to the number of petals produced by a flower. Here the meaning of doubleness is obviously quite different.

In the wild-type and normal crested flower, the floret outer corolla lip is elliptical in shape and has an entire edge. By contrast, the spider flower type has a laciniated (split or notched) outer corolla lip resulting in flower heads that appear lacy or fringed. Introduction of the spider trait into various lines has occurred more slowly than that of the crested trait, perhaps because of its delicate appearance and generally shorter vase life. Some other ornamental plant species also have cultivars exhibiting a spider or laciniated flower type. Among the most popular is the chrysanthemum (Boase et al., 1997; Bremer and Humphries, 1993) and dahlia [Dahlia variabilis $(D$. coccinea Cav. $\times$ D. pinnata Cav.) (Asteraceae)] (American Dahlia Society, 2003). The spider and related Fuji, quill, brush, and thistle types of Dendranthema $\times$ grandiflorum have ray floret corollas that are tubular rather than split or notched like those of spider gerberas. The laciniated type of Dahlia variabilis has involute or revolute ray floret corollas that are split or notched and somewhat twisted or curled in the distal split portion. Although they are not identical, they resemble more closely the corollas of spider gerberas than the tubular corollas of spider chrysanthemums. We have observed that only uncommon gerbera variants have somewhat involute or revolute ray floret corollas.

Several investigators have examined the inflorescence and floret traits in the Davis population of $G$. hybrida using quantitative approaches (Drennan et al., 1986; Harding et al., 1990; Huang and Harding, 1998). Their studies estimated genetic variability and heritability in a variety of quantitative traits, including those of the inflorescence, scape, and florets. Narrow-sense heritability estimates were generally low $\left(\mathrm{h}^{2}<0.20\right)$ for enumeration characters, moderate $\left(h^{2}>0.20\right)$ for simple dimension characters and high $\left(\mathrm{h}^{2}>0.50\right)$ for characters evaluated as means (Drennan et al., 1986). A relatively high degree of phenotypic and genetic correlation was observed among the flower traits (Harding et al., 1990). A principal component analysis (Harding et al., 1991; James and McCulloch, 1990) restructured the original traits into composite traits in an attempt to gain quantitative information on developmental processes that determine the structure of the gerbera flower (Huang and Harding, 1998). The results of this analysis suggested that the quantitative genetic structure of the gerbera flower is controlled by a few independent components.

The objective of this study was to determine the mode of inheritance of the crested and spider flower types in G. hybrida. We used a mendelian genetic analysis designed to identify the major genes controlling these traits and evaluated allelic and linkage relationships (Griffiths et al., 1999).

\section{Materials and Methods}

Plant material. Gerbera hybrida used in experimental crosses were part of the North Carolina State Univ. (NCSU) gerbera collection. The collection was formed in 1996 and at that time was composed of 226 plants derived from 24 different cultivar lines [13 single (wild-type), 3 crested, 6 semi-crested, 1 single spider, and 1 semi-crested spider]. Twenty-one of the original lines were collected by the first author between 1985 and 1996 and were derived from seeds obtained from commercial sources and plants obtained from various nurseries located in North Carolina, Florida, and California. Also several plants of a wild-type flower and semi-crested flower line were obtained from R. Larson (Dept. of Horticultural Science, North Carolina State Univ., Raleigh) and seeds of wild-type flowers from the Davis population were obtained from J. Harding (Dept. of Environmental Horticulture, Univ. of California, Davis). The variety of cultivars making up the collection provided a reasonably good representation of genes determining each flower type.

In the present study, 163 wild-type, 97 crested, 184 semi-crested, 13 single spider, 7 crested spider, and 43 semi-crested spider gerbera plants were used as parents in crosses to gain information on the inheritance of flower types (Table 1). Thirty-one were the original plants obtained from cultivar lines mentioned above. The remainder was their progeny collected over a period of four generations of either line breeding or outcrossing. They were selected on the basis of flower type, ability to produce sufficient quantities of viable seed, and demonstration of good growth and longevity under greenhouse and field conditions.

GENETIC ANALYSIS. The genotype of each parent (Table 1) was determined by testcrosses (parent $\times$ wild type). For each flower type, a series of crosses were made to produce $\mathrm{P}_{\mathrm{A}}, \mathrm{P}_{\mathrm{B}}, \mathrm{F}_{1}, \mathrm{~F}_{2}, \mathrm{BC}_{1 \mathrm{~A}}$, and $\mathrm{BC}_{1 \mathrm{~B}}$ progeny. Allelism was tested operationally by crossing genotypes in all possible combinations and observing single-genepair ratios. Use of the complementation test for allelism was not appropriate for the dominant mutations observed in this study. Linkage relationships among the crested and spider loci were tested using dihybrid crosses and testcrosses. Progeny phenotypes were classified by the visual appearance of mature capitula of the first two to five flowers. Flowers usually appeared when the plant was 5 to 8 months of age. The capitulum was considered to be mature and at commercial stage when two rows of disk florets with exerted fused stamens were observed and trans and/or ray florets were fully extended. It was more difficult to assess the maturity of capitula among the group of full- or large-crested gerberas with disk florets not exerting fused stamens. Observations were made also on fully developed capitula and continued until they showed senescence to determine if fused stamens would eventually appear. The number and length of mature ray, trans, and disk florets from fully developed capitula of parents and several of their progeny were determined to provide key comparative data for each of the crested genotypes. An analysis of variance was performed by Fisher's protected least significant difference (PLSD) for making pair-wise comparisons (StatView version 5.0.1; SAS Inst., Cary, N.C.). The chi-square test was used to interpret phenotypic ratios and quantify the various deviations expected by chance.

All pollinations were done by hand in the greenhouse during daylight hours between November and April of each year (1998-2002). The flower of the seed parent was pollinated on the first or second day following exertion of stigmata. Pollination was repeated on 1 or $2 \mathrm{~d}$ more for crested gerberas in order to maximize seed production. In these gerberas, new whorls of stigmata were exposed as the trans florets and capitulum continued to mature. One or more flowers of the pollen parent were used as a source of pollen when stamens and their anthers were exerted from two or more rows of disk florets. Pollen extrusion was facilitated by firmly squeezing the involucre of bracts with 
Table 1. Number of different gerbera parents representing each phenotypic and genotypic class that were used in crosses.

\begin{tabular}{llrrrrrr}
\hline & \multicolumn{7}{c}{ Generation } \\
\cline { 2 - 8 } Phenotype $^{z}$ & Genotype $^{\mathrm{y}}$ & 1 & 2 & 3 & 4 & 5 & Total \\
\hline Full-crested & CrdCrspsp & 0 & 1 & 2 & 5 & 2 & 10 \\
Large-crested (ms) & Crdcrspsp & 0 & 0 & 4 & 4 & 1 & 9 \\
Large-crested & CrCrspsp & 0 & 1 & 18 & 25 & 34 & 78 \\
Semi-crested & Crcrspsp & 12 & 65 & 61 & 38 & 8 & 184 \\
Full-crested spider & CrdCrSpsp & 0 & 0 & 0 & 1 & 0 & 1 \\
Large-crested (ms) spider & CrdcrSpsp & 0 & 0 & 0 & 1 & 0 & 1 \\
Large-crested spider & CrCrSpsp & 0 & 0 & 4 & 1 & 0 & 5 \\
Semi-crested spider & CrcrSpSp & 0 & 2 & 3 & 0 & 0 & 5 \\
Semi-crested spider & CrcrSpsp & 1 & 3 & 14 & 17 & 3 & 38 \\
Single-flowered spider & crcrSpSp & 0 & 2 & 1 & 0 & 0 & 3 \\
Single-flowered spider & crcrSpsp & 0 & 3 & 3 & 4 & 0 & 10 \\
Single (wild-type) & crcrspsp & 18 & 67 & 51 & 26 & 1 & 163 \\
\hline
\end{tabular}

${ }^{2}$ Phenotypes: descriptions are for capitula developed to the commercial stage where at least two whorls of disk florets are mature. Full-crested, presence of ray, trans, and disk florets, but disk florets did not exert fused stamens (male-sterile, ms); outermost trans florets were approximately $80 \%$ to $90 \%$ as long as ray florets. Large-crested (ms), similar to the fullcrested flower type except that trans florets were somewhat shorter and some plants showed a few disk florets with exerted stamens in late-spring and summer. Large-crested, presence of ray, trans, and inconspicuous disk florets that usually exerted stamens; outermost trans florets are more than one-half the length of the ray florets. Semi-crested, similar to the largecrested flower type above except the length of the outermost trans florets was equal to or less than one-half the length of ray florets. Single (wild-type), presence of ray and inconspicuous trans and disk florets; disk florets exerted fused stamens. Spider, florets were split or notched (laciniated); crested, quasi-spider variants had laciniated trans and disk florets, but ligulate and/or slightly notched ray florets.

yAllelic symbols: $C r^{d}$, crested flower with enlarged trans and disk florets, male sterility; $\mathrm{Cr}$, crested flower with enlarged trans florets; $c r$, single (wild-type) flower; $S p$, florets laciniated; $s p$, wild-type ligulate florets.

the thumb and forefinger. Seeds were collected at maturity and stored in the refrigerator at $4{ }^{\circ} \mathrm{C}$.

Cultivation. Breeding plants were grown in Metro Mix 200 (Scotts-Sierra Horticultural Products Co., Marysville, Ohio) in standard $12,000 \mathrm{~cm}^{3}$ clay pots. During the months of Oct. through Apr. 1996-2003, they were placed $\approx 40 \mathrm{~cm}$ apart in three rows on raised benches in the greenhouse. Growing temperatures in the greenhouse ranged from 24 to $40{ }^{\circ} \mathrm{C}$ day/18 to $24{ }^{\circ} \mathrm{C}$ night. Light was extended from sunset to $2100 \mathrm{HR}$ at an intensity of 148 to $334 \mu \mathrm{mol} \cdot \mathrm{m}^{-2 \cdot} \cdot \mathrm{s}^{-1}$ at the flower surface with the use of $1000-\mathrm{W}$ metal halide lamps. Extended light was necessary to enhance flower production and pollen and seed yield. Potted plants were placed outdoors in full-sun on landscape cloth from May through September. The range of outdoor temperatures was slightly greater than that of the greenhouse. Plants were fertilized by the addition $36 \mathrm{~g}$ of 14N-6.1P-11.6K slow-release fertilizer (Osmocote; Scotts-Sierra) per pot at 3-month intervals. They also received monthly 1-L applications of $12 \mathrm{~N}-24.0 \mathrm{P}-5.0 \mathrm{~K}$ liquid fertilizer (Super Bloom; Green Light, San Antonio, Texas) at $11.5 \mathrm{~g} \cdot \mathrm{L}^{-1}$.

Seeds from the various crosses were germinated in the laboratory in clear plastic-covered, 48- or 72-cell flats filled with Metro Mix 200. Germination was facilitated by $12 \mathrm{~h}$ of lighting at an intensity of 55 to $60 \mu \mathrm{mol} \cdot \mathrm{m}^{-2} \cdot \mathrm{s}^{-1}$ using a $40-\mathrm{W}$ cool-white and $40-\mathrm{W}$ grow light. Temperatures ranged from 20 to $24{ }^{\circ} \mathrm{C}$ day/18 to $20{ }^{\circ} \mathrm{C}$ night. Germination was usually completed by day seven, at which time the plastic cover was removed. When seedlings were 1 month old, flats were moved to the greenhouse where growth was continued for an additional month. Seedlings were then either transferred to standard $1500 \mathrm{~cm}^{3}$ clay pots containing fresh Metro Mix 200 for growth in the greenhouse or planted outdoors in May for growth in raised beds exposed to full-sun. Seedlings from seeds germinated in July and August were potted for greenhouse cultivation; those from seeds germinated in January and February were grown in the field. Potted plants were placed $\approx 15 \mathrm{~cm}$ apart on raised benches in the greenhouse. Field-grown plants were spaced $\approx 25 \mathrm{~cm}$ apart in raised beds. Growth was continued in the greenhouse for at least 8 months or in the field until the end of September. Fertilization of young seedlings was initiated at the time when true leaves appeared (usually at 2 to 3 weeks of age) and included a weekly application of 20N-8.7P-16.6K liquid fertilizer (Peters Professional; Scotts-Sierra) at $5.8 \mathrm{~g} \cdot \mathrm{L}^{-1}$. Potted plants received $6 \mathrm{~g}$ of Osmocote $(14 \mathrm{~N}-6.1 \mathrm{P}-11.6 \mathrm{~K})$ per pot at 3 -month intervals. Monthly 200-mL applications of Super Bloom $(12 \mathrm{~N}-24.0 \mathrm{P}-5.0 \mathrm{~K})$ at $11.5 \mathrm{~g} \cdot \mathrm{L}^{-1}$ were initiated when flower buds first appeared. Plants grown in raised beds received twice the amount of fertilizer applied to potted plants, but at the same intervals. They were irrigated when necessary.

\section{Results and Discussion}

Genetic ANAlysis OF THE CRESTED Flower TYPE. Key characteristics of mature florets from fully developed capitula representing each of the crested genotypes (Table 1) are listed in Table 2. Testcrosses between different crested and wild-type gerberas of the NCSU collection produced progeny that were either crested in a 1:0 ratio or crested and wild type in a $1: 1$ ratio $\left(\chi^{2}=0.25\right.$ to $\left.0.42, P>0.5\right)$. These results are consistent with what would be expected if the crested flower type was under the control of a single dominant gene. Furthermore, most of the gerberas with large-crested flowers were homozygous and those with semi-crested flowers were heterozygous for this gene. Large-crested flowers had capitula with trans florets of the outermost whorl extending greater than one-half the length of the ray florets and semi-crested flowers had capitula with trans florets of the outermost whorl being equal to or less than one-half the length of ray florets. In the collection, two types of large-crested flowers could be distinguished (Fig. $1 \mathrm{C}$ and D). Both had mature capitula with ray and enlarged trans florets. However, in addition, one type had many whorls of conspicuous trans and disk florets appearing within the central disk area and was usually functionally male-sterile. The other type had an open central disk area and about two whorls of inconspicuous disk florets having exerted stamens with anthers extruding pollen. As the latter capitula approached senescence, the central disk area filled with whorls of inconspicuous disk florets. Testcrosses with plants exhibiting the male-sterile, large-crested flower type indicated that they were heterozygous for a crested and wild-type gene. By comparison, plants with the male-fertile, large-crested flower type were homozygous for a crested gene. At this point in the investigation, we were uncertain that the same gene controlling the male-fertile, large-crested flower type also controlled the male-sterile, large-crested flower type. Plants of the full-crested flower type (Fig. 1B) had many whorls of enlarged trans florets and also conspicuous trans and disk florets forming within the central disk area that together formed a crest covering 
Table 2. Mature floret characteristics of the different crested gerbera genotypes. ${ }^{z}$

\begin{tabular}{|c|c|c|c|c|c|c|c|c|c|}
\hline \multirow[b]{3}{*}{ Genotypes } & \multirow{2}{*}{\multicolumn{3}{|c|}{ Floret no./capitulumy }} & \multirow{2}{*}{\multicolumn{3}{|c|}{ Floret length $(\mathrm{mm})^{\mathrm{x}}$}} & \multicolumn{3}{|c|}{ Disk floret structure and function } \\
\hline & & & & & & & \multirow{2}{*}{$\begin{array}{c}\text { Stamen } \\
\text { configuration }\end{array}$} & \multirow{2}{*}{$\begin{array}{c}\text { Pollen } \\
\text { production }^{v}\end{array}$} & \multirow{2}{*}{$\begin{array}{c}\text { Pistil } \\
\text { position }^{u}\end{array}$} \\
\hline & Ray & Trans & Disk & Ray & Trans & Disk & & & \\
\hline$\overline{C r d} \mathrm{Cr}$ & $66 \pm 10$ & $282 \pm 35$ & $334 \pm 56$ & $55 \pm 9$ & $46 \pm 7$ & $29 \pm 3$ & separated & $\begin{array}{l}\text { very low, } \\
\text { sterile }\end{array}$ & exposed \\
\hline $\mathrm{Cr}^{\mathrm{d}} \mathrm{cr}$ & $62 \pm 11$ & $211 \pm 45$ & $370 \pm 45$ & $54 \pm 6$ & $39 \pm 5$ & $28 \pm 4$ & $\begin{array}{l}\text { separated } \\
\text { or fused }\end{array}$ & $\begin{array}{l}\text { seasonal:low } \\
\text { to moderate, } \\
\text { often sterile }\end{array}$ & $\begin{array}{l}\text { covered } \\
\text { or exposed }\end{array}$ \\
\hline $\mathrm{CrCr}$ & $66 \pm 12$ & $279 \pm 42$ & $346 \pm 38$ & $54 \pm 6$ & $41 \pm 6$ & $19 \pm 1$ & fused & $\begin{array}{l}\text { moderate to } \\
\text { high }\end{array}$ & covered \\
\hline $\mathrm{Crcr}$ & $63 \pm 11$ & $206 \pm 69$ & $361 \pm 76$ & $55 \pm 6$ & $30 \pm 4$ & $18 \pm 1$ & fused & high & covered \\
\hline $\mathrm{crcr}$ & $60 \pm 9$ & $211 \pm 65$ & $387 \pm 70$ & $53 \pm 6$ & $17 \pm 2$ & $16 \pm 1$ & fused & very high & covered \\
\hline
\end{tabular}

${ }^{2}$ Characteristics listed are for florets obtained from fully developed capitula just prior to senescence.

yata represent the mean and standard deviation of the floret number determined on capitula with an involucre base diameter of 1.8 to $2.0 \mathrm{~cm}$. Capitula with an involucre base diameter $<1.6 \mathrm{~cm}$ had fewer florets and those $>2.3 \mathrm{~cm}$ had more florets than those indicated above. No significant differences were detected among either ray or disk floret number means by the multiple comparison test Fisher's protected least significant difference (PLSD). $C r^{d} \mathrm{Cr}$ and $\mathrm{CrCr}$ genotypes appeared to have slightly more trans florets than $C r^{d} c r, C r c r$, and wild-type $c r c r$ genotypes $(P=0.02-0.06)$. xData represent the mean and standard deviation of floret length measured from the base of the attachment tube to the tip of the outer corolla (ligule) lip. No significant differences among the ray floret length means were detected by Fisher's PLSD. There was no significant difference between the trans floret means of the $\mathrm{CrCr}$ and $\mathrm{Cr}^{d} \mathrm{cr}$ genotypes. With the exception of this comparison, trans floret mean differences among genotypes were significant $(P<0.0001<0.05)$. From $0.3 \%$ to $2 \%$ of trans florets present in wild-type capitula were enlarged to the size of trans florets of the $\mathrm{Crcr}$ genotype. No significant differences were detected in the disk floret means of $\mathrm{Crcr}$ and wild-type $\mathrm{crcr}$ genotypes or between the means of $C r^{d} \mathrm{Cr}$ and $C r^{d} \mathrm{cr}$ genotypes. The difference in the disk floret means of $\mathrm{CrCr}$ and $\mathrm{crcr}$ genotypes was significant $(P<0.05)$. Differences in disk floret means of the $\mathrm{Cr} C \mathrm{Cr}$ and $\mathrm{Cr}^{d} \mathrm{cr}$ genotypes compared to the other genotypes were highly significant $(P<0.0001)$.

wIn the wild-type disk floret, normally four to five stamens were fused around a pistil forming a bright yellow-orange or orange anther. Stamens were loosely connected or separated in the disk floret of the $\mathrm{Cr} r^{d} \mathrm{Cr}$ genotype and in many of the disk florets of the $\mathrm{Cr}^{d} \mathrm{cr}$ genotype. They were dark brown or gray-black, perhaps indicating some deterioration related to the tight packing of enlarged disk florets in the center of the capitulum. $\checkmark$ The anther of the wild-type disk floret normally produced and released large clusters of pollen, especially during the afternoon of sunny days. Disk florets of the $C r^{d} \mathrm{Cr}$ genotype and many of the $C r^{d} \mathrm{cr}$ genotype did not release clusters of pollen, although small quantities of pollen were observed microscopically in association with each stamen. Flowers exhibiting this phenotype were functionally male-sterile. Some $\mathrm{Cr} d \mathrm{cr}$ heterozygotes developed anthers as a consequence of stamen fusion and became male-fertile during May through September.

uThe pistil was normally enclosed within the fused stamens of the wild-type disk floret. The disk floret of the $\mathrm{Cr}{ }^{d} \mathrm{Cr}$ and $\mathrm{Cr}{ }^{d} \mathrm{Cr}$ genotypes with separated stamens had an exposed pistil that was apparently not functional.

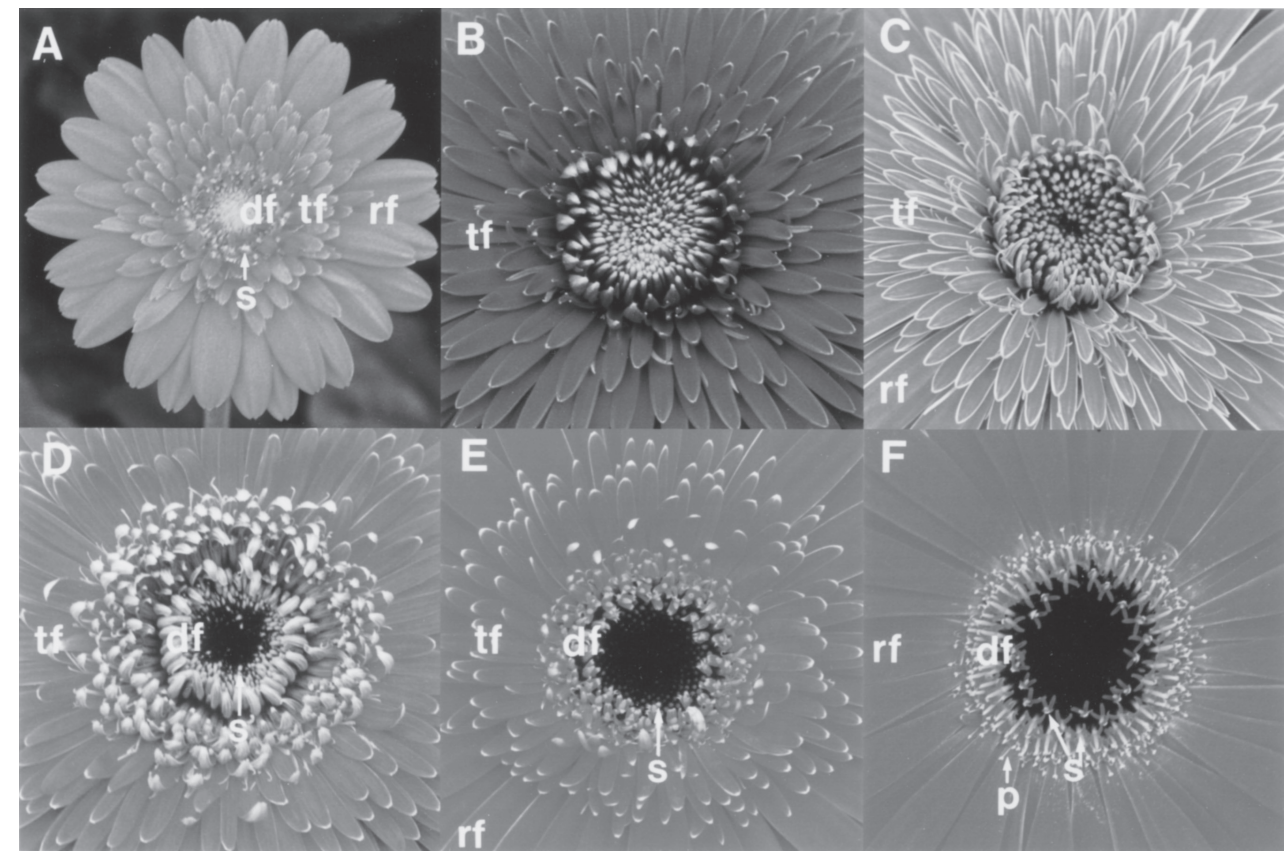

Fig. 1. Effect of different crested flower $(\mathrm{Cr})$ alleles on the phenotype of the gerbera capitulum at the commercial stage. Genotypes are given in parentheses. Allelic symbols: $\mathrm{Cr}^{d}$, crested flower with enlarged trans and disk florets, male-sterile; $\mathrm{Cr}$, crested flower with enlarged trans florets; cr, single (wild-type) flower. (A) Entire capitulum of the miniature gerbera 168-6 ( Crcr), showing ray (rf), trans (tf), and disk florets (df) with exerted stamens (s). B through F show the central region of the capitula of gerberas. (B) P3-19 $\left(\mathrm{Cr}^{d} \mathrm{Cr}\right)$ and (C) $988\left(\mathrm{Cr}^{d} \mathrm{Cr}\right)$ exhibit many whorls of enlarged trans florets (tf) and immature trans and disk florets (indistinguishable at this stage) that originate from within the disk and extend outward; they also have ray florets (rf) (rf of P3-19 not shown). (D) 1155 ( $\mathrm{CrCr}$ ) and (E) $12-5$ ( $\mathrm{Crcr}$ ) exhibit enlarged trans florets (tf) and very small disk florets (df) with exerted stamens (s); they also have ray florets (rf) (rf of 1155 not shown). (F) 64-2 (wild type, crcr) shows ray florets (rf) and very small trans florets with exerted pistils (p) and very small disk florets (df) with exerted stamens (s). $(\times 0.68)$ 
Table 3. Phenotypic segregation ratios resulting from crosses between gerbera plants with different combinations of $\mathrm{Cr}$ alleles.

\begin{tabular}{|c|c|c|c|c|c|c|c|c|c|}
\hline \multirow[b]{3}{*}{ Cross } & \multicolumn{5}{|c|}{ Progeny phenotype ${ }^{z}$} & \multirow[b]{3}{*}{ Total } & \multirow{2}{*}{\multicolumn{3}{|c|}{$\begin{array}{l}\text { a Ratio (Crested(ms)/Crested) } \\
\text { b Ratio (Crested/Wild-type) }\end{array}$}} \\
\hline & \multicolumn{4}{|c|}{ Crested } & \multirow{2}{*}{$\begin{array}{l}\text { Wild- } \\
\text { type }\end{array}$} & & & & \\
\hline & Full & Large & Large $(\mathrm{ms})$ & Semi & & & Expected & $\chi^{2}$ & $P$ \\
\hline Full-crested $\left(\mathrm{Cr}^{d} \mathrm{Cr}\right)$ & & & & & & & a $1: 1$ & 0.01 & $>0.9$ \\
\hline $\mathrm{X}$ wild-type $(\operatorname{crcr})(\mathrm{n}=6)$ & 0 & 1 & 34 & 34 & 0 & 69 & b $1: 0$ & 0 & 1 \\
\hline Large-crested $(\mathrm{CrCr})$ & & & & & & & a $0: 1$ & 0 & 1 \\
\hline $\mathrm{X}$ wild-type $(\mathrm{crcr})(\mathrm{n}=27)$ & 0 & 11 & 0 & 393 & 0 & 404 & b $1: 0$ & 0 & 1 \\
\hline Large-crested (ms) $\left(\mathrm{Cr}^{d} \mathrm{cr}\right)$ & & & & & & & a $2: 1$ & 0.33 & $>0.5$ \\
\hline $\mathrm{X}$ semi-crested $(\mathrm{Crcr})(\mathrm{n}=8)$ & 25 & 6 & 39 & 30 & 31 & 131 & b $3: 1$ & 0.12 & $>0.5$ \\
\hline Semi-crested $(\mathrm{Crcr})$ & & & & & & & a $0: 1$ & 0 & 1 \\
\hline$X$ semi-crested $(C r c r)(n=145)$ & 0 & 351 & 0 & 1285 & 541 & 2177 & b $3: 1$ & 0.02 & $>0.5$ \\
\hline Large-crested $(\mathrm{ms})\left(\mathrm{Cr} r^{d} \mathrm{cr}\right)$ & & & & & & & a $1: 0$ & 0 & 1 \\
\hline $\mathrm{X}$ wild-type $(\operatorname{crcr})(\mathrm{n}=8)$ & 0 & 0 & 37 & 0 & 42 & 79 & b $1: 1$ & 0.32 & $>0.5$ \\
\hline Semi-crested $(\mathrm{Crcr})$ & & & & & & & a $0: 1$ & 0 & 1 \\
\hline $\mathrm{X}$ wild-type $(\mathrm{crcr})(\mathrm{n}=85)$ & 0 & 24 & 0 & 572 & 573 & 1169 & b $1: 1$ & 0.45 & $>0.5$ \\
\hline Full-crested $\left(\mathrm{Cr} r^{d} \mathrm{Cr}\right)$ & & & & & & & a $1: 1$ & 0.32 & $>0.5$ \\
\hline X semi-crested $(C r c r)(\mathrm{n}=19)$ & 70 & 78 & 52 & 53 & 0 & 253 & b $1: 0$ & 0 & 1 \\
\hline Large-crested $(\mathrm{CrCr})$ & & & & & & & a $1: 1$ & 0.01 & $>0.9$ \\
\hline $\mathrm{X}$ large-crested $(\mathrm{ms})\left(\mathrm{Cr}^{d} \mathrm{cr}\right)(\mathrm{n}=6)$ & 36 & 2 & 0 & 35 & 0 & 73 & b $1: 0$ & 0 & 1 \\
\hline Large-crested $(\mathrm{CrCr})$ & & & & & & & a $0: 1$ & 0 & 1 \\
\hline X semi-crested $(C r c r)(\mathrm{n}=97)$ & 0 & 618 & 0 & 703 & 0 & 1321 & b $1: 0$ & 0 & 1 \\
\hline Full-crested $\left(\mathrm{Cr}^{d} \mathrm{Cr}\right)$ & & & & & & & a $1: 1$ & 1.0 & $>0.1$ \\
\hline $\mathrm{X}$ large-crested $(\mathrm{CrCr})(\mathrm{n}=5)$ & 36 & 29 & 0 & 16 & 0 & 81 & b $1: 0$ & 0 & 1 \\
\hline Large-crested $(\mathrm{CrCr})$ & & & & & & & a $0: 1$ & 0 & 1 \\
\hline $\mathrm{X}$ large-crested $(\mathrm{CrCr})(\mathrm{n}=21)$ & 0 & 216 & 0 & 96 & 0 & 312 & b $1: 0$ & 0 & 1 \\
\hline Wild-type (crcr) & & & & & & & & & \\
\hline$X$ wild-type $(\operatorname{crcr})(\mathrm{n}=92)$ & 0 & 0 & 0 & 0 & 1270 & 1270 & b $0: 1$ & 0 & 1 \\
\hline
\end{tabular}

zPhenotypes and allelic symbols have been described in the footnotes of Table 1. Spider genotype and phenotype data are not given.

$80 \%$ to $90 \%$ the length of ray florets. This crest gave the flower a ball or domed shape. Plants of the full-crested flower type were male-sterile. Testcrosses suggested they were homozygous for a crested gene. Although all progeny were crested, about one-half were the male-sterile, large-crested flower type and the other half were the male-fertile, semi-crested flower type. This suggested that full-crested plants were heterozygotes having two different dominant alleles determining the crested trait, designated $\mathrm{Cr}^{d}$ (crested flower with enlarged trans and disk florets, male-sterile) and $\mathrm{Cr}$ (crested flower with enlarged trans florets). The recessive wild-type allele was designated $c r$.

The pooled results of crosses between crested and wild-type gerberas representing each phenotypic and genotypic class are given in Table 3 . The mature capitula of selected gerberas representing each of the above classes are shown in Fig. 2. Wild-type parents $\left(\mathrm{P}_{\mathrm{A}}\right)$ (Fig. 2L) when crossed to one another produced only wild-type progeny. $\mathrm{Cr}$ homozygotes $\left(\mathrm{P}_{\mathrm{B}}\right)$ (Fig. $2 \mathrm{~F}, \mathrm{G}$, and $\mathrm{H}$ ) when crossed to one another produced only male-fertile, crested progeny. However, not all had flowers with crests as large as the parents. Thirty-one percent had semi-crested or borderline semi-crested capitula. The capitulum of most of the male-fertile, large-crested progeny had fewer stamens extruding large clusters of pollen than that of the semi-crested or wild type.

$\mathrm{F}_{1}$ progeny resulting from all crosses between $\mathrm{Cr}$ homozygotes and wild-type ( $\mathrm{crcr}$ ) plants exhibited the crested trait and of these

Fig. 2. Mature capitula of representative gerberas having different combinations of crested flower $(\mathrm{Cr})$ alleles. Genotypes are given in parentheses. Allelic symbols: $\mathrm{Cr}^{d}$, crested flower with enlarged trans and disk florets, male sterile; $\mathrm{Cr}$, crested flower with enlarged trans florets; $\mathrm{cr}$, single (wild-type) flower. (A) 553-2 (Cridr). (B) $1239\left(\mathrm{Cr}^{d} \mathrm{Cr}\right)$. (C) $1313\left(\mathrm{Cr}^{d} \mathrm{Cr}\right)$. (D) $803\left(\mathrm{Cr}^{d} \mathrm{Cr}\right)$. (E) 1315 (Crdcr). (F) 711 ( $\mathrm{CrCr}$ ). (G) 194-15 (CrCr). (H) 144-4 (CrCr). (I) 12-4 (Crcr). (J) 20-10 (Crcr). (K) 556-11 (Crcr). (L) 160-11 (wild type, crcr). $(\times 0.27)$

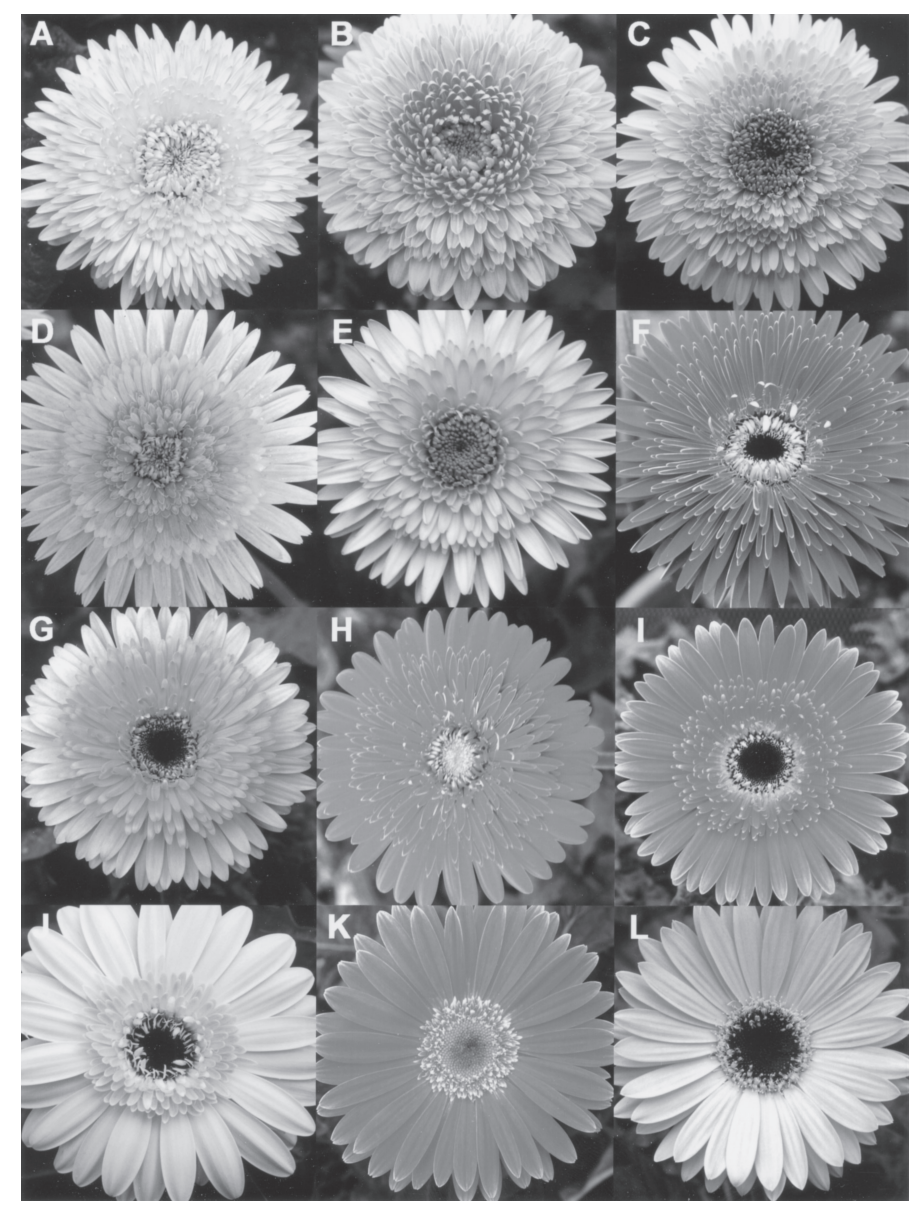


97\% were semi-crested and 3\% were large-crested flower types. The relative size of the crest (length of outermost trans florets/ length of ray florets) of different $\mathrm{Crcr}$ semi-crested progeny varied considerably. The wide variation in trans floret size observed at the commercial stage supports the earlier observations of Drennan et al. (1986) indicating a high SD for the length of the inner and outer corolla lips of trans florets. Depending on the particular plant, trans florets in the outermost whorl extended from $12 \%$ to $50 \%$ of the length of ray florets (Fig. 2 I, J, and K). On capitula with very short trans florets (Fig. $2 \mathrm{~K}$ ), the crest appeared as a collar surrounding the central disk area. These capitula usually contained trans florets of two different lengths. Trans florets forming the collar were the longest and the wild-type trans florets, positioned next to the disk florets, the shortest. The frequency of this flower subtype among $\mathrm{F}_{1}$ progeny was in a range of $0 \%$ to $44 \%$, depending on the particular cross. It is probably not determined by a different allele for it is relatively common among $\mathrm{BC}_{1 \mathrm{~A}}$ and $\mathrm{BC}_{1 \mathrm{~B}}$ progeny. In backcrosses between four $\mathrm{F}_{1}$ plants with very short trans florets and the wild type, the progeny were either semi-crested or wild type in a $1: 1$ ratio $\left(\chi^{2}=0.32\right.$ to $0.41, P$ $>0.5$ ). Seventy-five percent to $100 \%$ of the semi-crested progeny had capitula with very short trans florets, suggesting the possibility that this subtype is representing one of the limits defined by a nearly homozygous set of modifying genes affecting the size of trans florets associated with the crested trait.

The $\mathrm{F}_{2}$ generation segregated in the ratio 3 crested : 1 wild type (Table 3 ) as would be expected if the crested trait was determined by a single gene $(\mathrm{Cr})$ that was dominant to the gene ( $\mathrm{cr}$ ) determining the wild-type phenotype. One could argue that dominance is not complete, since generally the $C r$ homozygote had a capitulum with longer trans florets than the $\mathrm{Crcr}$ heterozygote. Twenty-one percent of the crested progeny were large-crested and 79\% were semi-crested. Ninety-six percent of the large-crested progeny tested were $C r$ homozygotes and $80 \%$ of the semi-crested progeny tested were $\mathrm{Crcr}$ heterozygotes. The probability of a plant being a crested homozygote appears to be directly proportional to the relative size of the crest. The relative size of the crest varied $\approx 10 \%$ to $20 \%$ with the season; it was usually smallest in the summer and largest in the winter. It may also vary somewhat among different capitula on the same plant measured at the same time, but was usually $10 \%$ or less.

The $\mathrm{BC}_{1 \mathrm{~A}}$ generation segregated as expected in a ratio of 1 crested : 1 wild type (Table 3). Four percent of the progeny were large-crested and $96 \%$ were semi-crested. All of the $\mathrm{BC}_{1 \mathrm{~B}}$ progeny exhibited the crested trait in a ratio of 1 large-crested : 1 semi-crested.

Based on the results of testcrosses, there were no plants homozygous for the $C r^{d}$ allele in the NCSU collection. None were identified among the few progeny obtained from crosses between uncommon $\mathrm{Cr}^{d} \mathrm{cr}$ heterozygotes that were male-fertile during late-spring and summer. Crosses between $\mathrm{Cr}$ homozygotes and $\mathrm{Cr}^{d} \mathrm{Cr}$ heterozygotes (Fig. 2 A and B) resulted in $44 \%$ male-sterile, full-crested, $36 \%$ large-crested, and 20\% semi-crested progeny. Crosses between $\mathrm{Cr}^{d} \mathrm{Cr}$ heterozygotes and wild type produced progeny exhibiting only the crested trait in a ratio of 1 male-sterile, large-crested : 1 semi-crested (Table 3). Crosses between $\mathrm{Cr}^{d} \mathrm{cr}$ (Fig. 2 C, D, and E) and $\mathrm{Crcr}$ heterozygotes produced progeny in a ratio of 3 crested: 1 wild type. The crested progeny were in a ratio of 1 male-sterile, full-crested: 1 male-sterile, large-crested : 1 semi-crested. Furthermore, the ratio of male-sterile to malefertile, crested flower types was $2: 1$, which together with the above results would be expected if the male-sterile, crested flower type was determined by an allele $\left(\mathrm{Cr}^{d}\right)$ that was dominant to the $\mathrm{Cr}$ and $c r$ alleles. Therefore, we are proposing the multiple allelic series $C r d>C r>c r$. Additional evidence for the allelic relationships was provided by the $\mathrm{BC}_{1 \mathrm{~A}}$ generation that segregated in a ratio of 1 male-sterile, large-crested : 1 wild type, although $5 \%$ of large-crested progeny were seasonally male-sterile/fertile. As expected, crosses between $C r^{d} c r$ heterozygotes and $\mathrm{Cr}$ homozygotes produced progeny exhibiting only the crested trait, segregating in a ratio of 1 male-sterile, full-crested : 1 semi-crested. Crosses between the $\mathrm{Cr}$ Cr and $\mathrm{Crcr}$ heterozygotes also produced only crested progeny and likewise segregated in a ratio of 1 male-sterile : 1 male-fertile phenotype. The above segregation ratios and the similarity of phenotype associated with $C r^{d}$ heterozygotes from crosses made over several generations with different cultivar lines support the existence of a second dominant allele determining the crested flower type that not only determines an increase in size of trans florets, like the $\mathrm{Cr}$ allele, but also increases the size of disk florets. However, one should also consider the possibility that instead of a different allele, a separate modifying gene might be closely linked to the $\mathrm{Cr}$ gene affecting its expression. Future fine structure mapping and/or nucleotide sequence comparisons might help resolve these alternative explanations. Numerous reports of multiple allelic series identified in animal (Hutt and Rasmusen, 1982) and plant (King, 1974) species apparently have not taken into consideration the role of a modifying gene, perhaps because of a perceived improbability or difficulty in obtaining conclusive evidence by classical mapping strategies.

Since mature flowers having the $C r^{d}$ allele do not show an open central disk area, they may not be as commercially desirable as the $\mathrm{Cr}$ homozygotes or $\mathrm{Crcr}$ heterozygotes. Except for floret structure, the globular form mimics that of the decorative chrysanthemums, which we find attractive. The increased weight of the capitulum in the $\mathrm{Cr}^{d} \mathrm{Cr}$ heterozygotes, as a consequence of having larger and somewhat more trans florets and larger disk florets, increases the risk of broken or bent stems during cultivation. Breeders might make this attractive flower type easier to cultivate by developing plants with shorter and stronger stems.

Studies on the inheritance of flower types in other ornamental plant species have shown that double flowers can be produced by either recessive or dominant mutations. In $D$. $\times$ grandiflorum, an aneuploid hexaploid, singleness appeared to be partially dominant over doubleness since single flowers were more frequent in single $\times$ double crosses (De Jong and Drennan, 1984). However, considering that $D$. $\times$ grandiflorum forms a polyaneuploid complex, the authors have suggested that it is possible that each set of chromosomes carries alleles for flower doubleness making this species unsuitable for classical mendelian genetic studies. Chrysanthemum-like, flower doubleness was determined by a recessive allele in the china aster [Callistephus chinensis (L.) Nees (Asteraceae)] (Raghava and Negi, 2001; Wit, 1937). Chrysanthemum-flowered sunflowers attribute their double appearance to the enlargment of disk florets that is determined by at least two dominant genes (Fick, 1976). The recessive PLENA mutant of Antirrhinum majus causes a homeotic conversion of stamens to petals, resulting in flower doubleness (Bradley et al., 1993). Flower doubleness in Dianthus caryophyllus (Saunders, 1917; Scovel et al., 1998), Pelargonium hortorum (Nugent and Snyder, 1967), and Petunia hybrida (Natarella and Sink, 1971; Van der Krol and Chua, 1993) was determined by dominant alleles. In Dianthus caryophyllus, double-flowered cultivars showed a homeotic conversion of stamens to petals and usually did not have stamens, whereas semi-double and single cultivars had fertile 
stamens. The proliferation of petals associated with the dominant allele is believed to be due to meristic effects and the homeotic conversion of stamens to petals (Scutt et al., 1999).

Genetic ANALYSIS OF THE SPIDER FlOWER TYPE. Testcrosses between spider (laciniated florets) and wild-type (ligulate florets) gerberas of the NCSU collection (Table 1) produced progeny that were either spider in a 1:0 ratio or spider and wild type in a $1: 1$ ratio $\left(\chi^{2}=0.35\right.$ to $\left.0.44, P>0.5\right)$. These results are consistent with what would be expected if the spider flower type was under the control of a single dominant gene, which we have designated $S p$. The wild-type gene was designated $s p$. Figure 3 illustrates the range of variation in laciniation observed among ray florets of spider parents. The developmental basis for the laciniated phenotype has not been determined, but one attractive hypothesis is that it is due, at least in part, to a failure in petal lobe fusion. Bremer (1994) and Kotilainen et al. (1999) have reported that the ligule of gerberas with normal florets results from a fusion of three petal lobes.

Pooled segregation data obtained from crosses testing the monohybrid inheritance of the spider flower type are given in Table 4. The mature capitula of selected spider gerberas representing each of the crested phenotypic and genotypic $\left(\mathrm{Cr}^{d}, \mathrm{Cr}, \mathrm{Cr}\right)$ classes are shown in Fig. 4. Wild-type parents $\left(\mathrm{P}_{\mathrm{A}}\right)$ when crossed to one another produced only wild-type progeny. $S p$ homozygotes $\left(\mathrm{P}_{\mathrm{B}}\right)$ when crossed to one another produced only spider progeny. All $\mathrm{F}_{1}$ progeny were of the spider flower type.

The $\mathrm{F}_{2}$ generation segregated in the ratio 3 spider : 1 wild type as would be expected if the spider flower type was determined by a single gene that was dominant to the wild-type gene (Table 4). The number of pointed lobes and depth of the splitting of florets varied considerably among the spider progeny. There was a good correlation between the number of floret lobes and depth of splitting. For many of the progeny, the number of lobes was variable for different florets from the same capitulum, e.g., 3 and 4, 3 to 5,4 and 5, 4 to 6,5 to 7 , and 5 to 8 . Capitula containing mainly deeply split ray florets were frilly or fluffy in appearance (Fig. 4 I and $\mathrm{J}$ ), whereas those containing shallow notched ray florets were fringed or saw-tooth in appearance (Fig. 4L). In 24 (92\%) of the crosses, dominance appeared to be complete. However, in two of the crosses, $12 \%$ and $22 \%$ of the crested Spsp heterozygotes had capitula with laciniated trans and disk florets, but normal ligulate and/or slightly notched ray florets (quasi-spider). Quasi-spider parents (Fig. 4 B, D, and G) produced a higher percentage of quasi-spider progeny than did parents of the classic spider type. All quasi- and classic spider parents producing $\mathrm{F}_{2}$ and backcross quasi-spider progeny, albeit in a low frequency, came from one of the two spider cultivar lineages in the collection. Whether the $S p$ gene from this lineage is the same allele as the $S p$ gene from the other lineage remains to be determined.

The $\mathrm{BC}_{1 \mathrm{~A}}$ generation segregated as expected in a ratio of 1 spider : 1 wild type (Table 4 ). In six (12\%) of the 49 crosses, $7 \%$ to $54 \%$ of the crested $S p$ heterozygotes were the quasi-spider flower type. All of the $\mathrm{BC}_{1 \mathrm{~B}}$ progeny were of spider flower type. In two $(22 \%)$ of the nine crosses, $25 \%$ of the crested $S p$ heterozygotes were the quasi-spider flower type.

LinKage anAlysis of THE $\boldsymbol{C r}$ AND $\boldsymbol{S p}$ LOCI. Linkage relationships of genes were analyzed using dihybrid crosses and testcrosses, where the crested spider parents had allelic combinations in repulsion (Table 5). The resulting phenotypic segregation ratios indicated that the $C r$ and $S p$ genes segregated independently. The lack of evidence for linkage was not surprising considering the relatively large number of somatic chromosomes $(2 \mathrm{n} \cong 50)$ present in the gerbera. There were no $C r d S p$ or $C r S p$ homozygotes in the collection to produce heterozygotes with the coupling arrangement.

This study examined the inheritance of several of the common flower types observed among cultivated gerberas. Major genes controlling the various phenotypes were identified by a mendelian genetic analysis. Since major dominant genes determine the crested and spider flower traits, the ease and monitoring of their distribution to various cultivar lines would be greatly facilitated. We have yet to determine the mode of inheritance of several of the uncommon trans and ray floret types, such as the attractive incurved trans and disk florets of certain crested flower types, recurved trans and ray florets of certain ball flower types, and involute or revolute ray florets of single-flowered types. Additional studies, especially

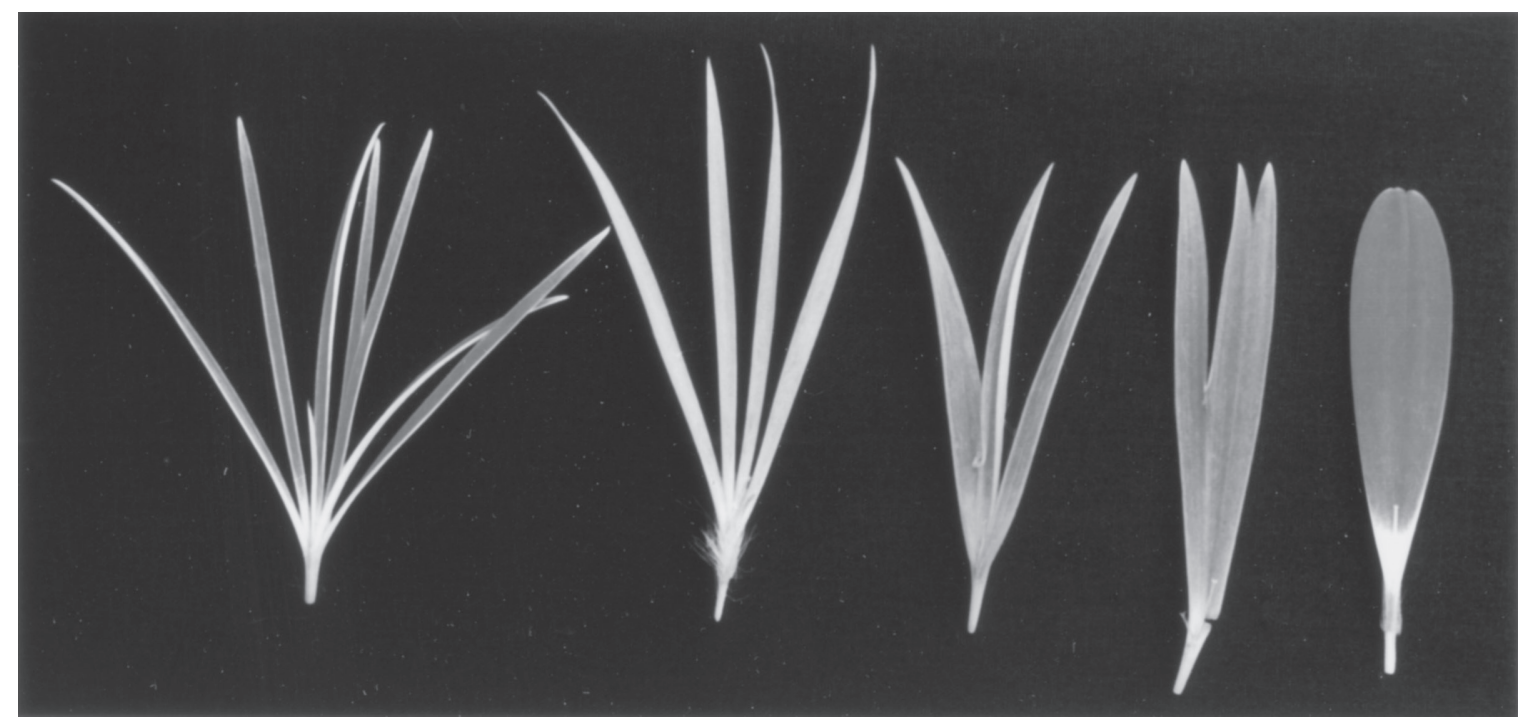

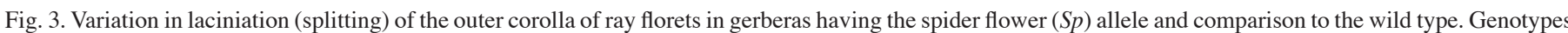

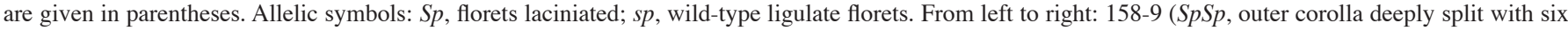

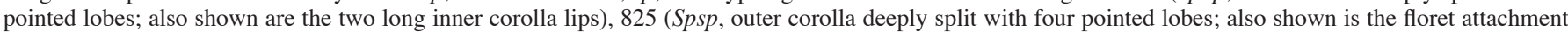

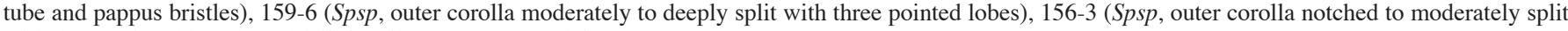
with three pointed lobes), and 160-9 (wild type, spsp). $(\times 1.2)$ 
Table 4. Phenotypic segregation ratios resulting from crosses between gerbera plants with different combinations of $S p$ alleles.

\begin{tabular}{|c|c|c|c|c|c|c|c|}
\hline \multirow[b]{2}{*}{ Cross } & \multicolumn{3}{|c|}{ Progeny phenotypez } & \multirow[b]{2}{*}{ Total } & \multicolumn{3}{|c|}{ Ratio (Spider/Wild-type) } \\
\hline & Spider & Quasi-spider $^{y}$ & Wild-type $^{x}$ & & Expected & $\chi^{2}$ & $P$ \\
\hline$\overline{\text { Spider }(S p S p)}$ & & & & & & & \\
\hline $\mathrm{X}$ wild-type $(\operatorname{spsp})(\mathrm{n}=1)$ & 92 & 0 & 0 & 92 & $1: 0$ & 0 & 1 \\
\hline Spider (Spsp) & & & & & & & \\
\hline $\mathrm{X}$ spider $(\operatorname{Spsp})(\mathrm{n}=26)$ & 243 & 5 & 76 & 324 & $3: 1$ & 0.41 & $>0.5$ \\
\hline Spider (Spsp) & & & & & & & \\
\hline $\mathrm{X}$ wild-type $(\operatorname{spsp})(\mathrm{n}=49)$ & 340 & 13 & 384 & 737 & $1: 1$ & 1.36 & $>0.1$ \\
\hline Spider $(S p S p)$ & & & & & & & \\
\hline $\mathrm{X}$ spider $(\operatorname{Spsp})(\mathrm{n}=9)$ & 111 & 3 & 0 & 114 & $1: 0$ & 0 & 1 \\
\hline Spider $(S p S p)$ & & & & & & & \\
\hline $\mathrm{X}$ spider $(S p S p)(\mathrm{n}=3)$ & 101 & 0 & 0 & 101 & $1: 0$ & 0 & 1 \\
\hline Wild-type (spsp) & & & & & & & \\
\hline $\mathrm{X}$ wild-type $(\operatorname{spsp})(\mathrm{n}=431)$ & 0 & 0 & 5971 & 5971 & $0: 1$ & 0 & 1 \\
\hline
\end{tabular}

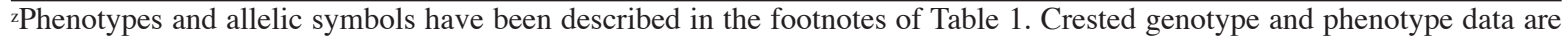
not given.

yQuasi-spider: plants exhibiting this phenotype were Spsp heterozygotes and were classified as spiders for calculating spider/ wild type ratios. One unusual semi-crested, spider plant, no. 1138 of genotype $C{ }^{d} c r S p s p$, had three crowns producing flowers with spider capitula and one crown with quasi-spider capitula at 1 year of age.

xFrom $0.5 \%$ to $2 \%$ of florets present in wild-type capitula were laciniated.

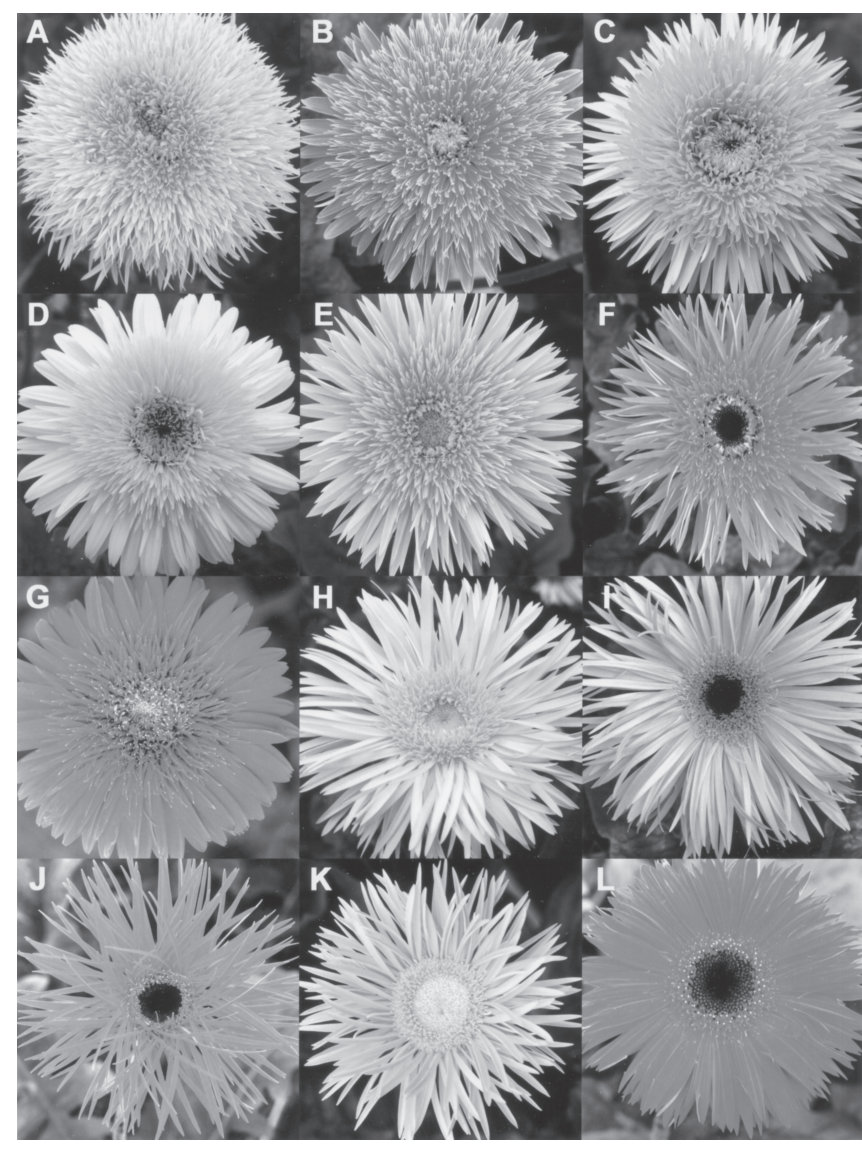

Fig. 4. Mature capitula of representative spider gerberas having different combinations of crested $(\mathrm{Cr})$ alleles. Genotypes are given in parentheses. Allelic symbols: $C r^{d}$, crested flower with enlarged trans and disk florets, male-sterile; $\mathrm{Cr}$, crested flower with enlarged trans florets; $\mathrm{cr}$, single (wild-type) flower; $\mathrm{Sp}$, florets laciniated; $s p$, wild-type ligulate florets. (A) 160-10 ( $\left.\mathrm{Cr}^{d} \mathrm{CrSpsp}\right)$.(B) $172-$ $4\left(\mathrm{Cr}^{d} \mathrm{CrSpsp}\right)$, variant with normal and slightly notched ray florets. (C) 160-7 $\left(C r^{d} \mathrm{crSpSp}\right.$ ). (D) 33-5 (CricrSpsp), variant with normal and slightly notched ray florets. (E) 250-5 (CrCrSpsp). (F) 245-17 (CrcrSpsp). (G) 1154 (CrcrSpsp), variant with normal and slightly notched ray florets. (H) 718 (CrcrSpsp). (I) 133-12 (CrcrSpsp). (J) 158-9 (crcrSpSp), ray florets deeply split with 5 to 6 pointed lobes. (K) 159-6 ( $\operatorname{crcrSpsp}$ ), ray florets moderately to deeply split with two to four pointed lobes. (L) 152-3 ( $\operatorname{crcrSpsp}$ ), ray florets notched or slightly split with two to three pointed lobes. $(\times 0.25)$ those at the molecular level will be needed to gain insight into the possible role of crested and spider genes in the regulation of gerbera flower development. The length of gerbera ray corollas and their cells have been shown to be regulated by the $G E G$ [for Gerbera hybrida homolog of the gibberellin (GA)-stimulated transcript 1 (GAST1) from tomato (Lycopersicon esculentum Mill.)] gene whose gene product shares high similarity to cell wall proteins encoded by GA-inducible genes in the tomato, petunia, and Arabidopsis thaliana (L.) Heynh. (Kotilainen et al., 1999). The primary role of $G E G$ appears to be the inhibition of cell elongation. Transgenic plants that expressed $G E G$ constitutively had shorter ray corollas and cells, reflecting an inhibition of cell expansion in the longitudinal direction. The $\mathrm{Cr}^{d}$ and $\mathrm{Cr}$ genes proposed in the present study appear to have the primary role of elongating the corollas of trans and disk florets and trans florets, respectively. An attractive hypothesis to consider would be the encoding of an inhibitor of $G E G$ expression by the $\mathrm{Cr}$ genes that would allow further cell elongation in specific florets that otherwise would have very small corollas.

\section{Literature Cited}

Almouslem, A.B. and R.A.E. Tilney-Basset. 1989. The inheritance of flower doubleness and nectary spur in Pelargonium hortorum. Euphytica 41:23-29.

American Dahlia Society. 2003. Classification and handbook of dahlias. Suppl. Bul. Amer. Dahlia Soc. 90:1-100.

Boase, M.R., R. Miller, and S.C. Deroles. 1997. Chrysanthemum systematics, genetics, and breeding. Plant Breeding Rev. 14:321-361.

Bradley, D., R. Carpenter, H. Sommer, N. Hartley, and E. Coen. 1993. Complimentary floral homeotic phenotypes result from opposite orientations of a transposon at the PLENA locus of Antirrhinum. Cell 72:85-95.

Bremer, K. 1994. Asteraceae, cladistics and classification. Timber Press, Portland, Ore.

Bremer, K. and C.J. Humphries. 1993. Generic monograph of the Asteraceae-Anthemidae. Bul. Natural History Museum. London (Bot.) 23:71-177.

De Jong, J. and D.L. Drennan. 1984. Genetic analysis in Chrysanthemum morifolium. II. Flower doubleness and ray floret corolla splitting. Euphytica 33:465-470.

Drennan, D., J. Harding, and T.G. Byrne. 1986. Heritability of inflores- 
Table 5. Phenotypic segregation ratios resulting from gerbera dihybrid crosses and testcrosses for the analysis of linkage of $\mathrm{Cr}$ and $\mathrm{Sp}$ loci.

\begin{tabular}{|c|c|c|c|c|c|c|c|c|}
\hline \multirow[b]{2}{*}{ Cross $^{y}$} & \multicolumn{4}{|c|}{ Progeny phenotype ${ }^{z}$} & \multirow[b]{2}{*}{ Total } & \multirow[b]{2}{*}{$\begin{array}{c}\text { Ratio } \\
\text { expected }\end{array}$} & \multirow[b]{2}{*}{$\chi^{2}$} & \multirow[b]{2}{*}{$P$} \\
\hline & $\begin{array}{c}\text { Crested } \\
\text { spider }\end{array}$ & Crested & $\begin{array}{l}\text { Single } \\
\text { spider }\end{array}$ & $\begin{array}{l}\text { Wild- } \\
\text { type }\end{array}$ & & & & \\
\hline \multicolumn{9}{|l|}{ Dihybrid: } \\
\hline \multicolumn{9}{|l|}{ Semi-crested spider (CrcrSpsp) } \\
\hline $\begin{array}{l}\text { X semi-crested spider (CrcrSpsp) } \\
(\mathrm{n}=12)\end{array}$ & 85 & 26 & 34 & 9 & 154 & $9: 3: 3: 1$ & 1.26 & $>0.5$ \\
\hline \multicolumn{9}{|l|}{ Testcross: } \\
\hline \multicolumn{9}{|l|}{ Semi-crested spider (CrcrSpsp) } \\
\hline$X$ wild-type $($ crcrspsp) $(\mathrm{n}=4)$ & 26 & 27 & 28 & 28 & 109 & $1: 1: 1: 1$ & 0.10 & $>0.97$ \\
\hline Recombinant vs. nonrecombinant & $\mathrm{R}$ & NR & NR & $\mathrm{R}$ & & $1: 1$ & 0.01 & $>0.97$ \\
\hline
\end{tabular}

cence and floret traits in Gerbera. Euphytica 35:319-330.

Fick, G.N. 1976. Genetics of floral color and morphology in sunflowers. J. Hered. 67:227-230.

Griffiths, A.J.F., W.M. Gelbart, J.H. Miller, and R.C. Lewontin. 1999. Modern genetic analysis, p. 105-174. Freeman, New York.

Hansen, H.V. 1999. A story of the cultivated Gerbera. The New Plantsman (Royal Hort. Soc.) 6:85-95.

Harding, J., T. Byrne, H. Huang, and Y. Yu. 1991. Multi-trait selection in flower crops, p. 158-178. In: J. Harding, F. Singh, and J. Mol (eds.). Genetics and breeding of ornamental species. Kluwer, Dordrecht, The Netherlands.

Harding, J., T.G. Byrne, and R.L. Nelson. 1981. Estimation of heritability and response to selection for cut-flower yield in gerbera. Euphytica 30:313-322.

Harding, J., H. Huang, T. Byrne, and N. Huang. 1990. Quantitative analysis of correlation among flower traits. I. Genetic and environmental correlation. Theor. Appl. Genet. 80:552-558.

Helariutta, Y., M. Kotilainen, P. Elomaa, and T.H. Teeri. 1995. Gerbera hybrida (Asteraceae) imposes regulation at several anatomical levels during inflorescence development on the gene for dihydroflavonol-4reductase. Plant Mol. Biol. 28:935-941.

Huang, H. and J. Harding. 1998. Quantitative analysis of correlations among flower traits in Gerbera hybrida, Compositae. III. Genetic variability and structure of principle component traits. Theor. Appl. Genet. 97:316-322.

Hutt, F.B. and B.A. Rasmusen. 1982. Animal genetics, p. 236-249. Wiley, New York.

James, F. and C. McCulloch. 1990. Multivariate analysis in ecology and systematics: Panacea or Pandora's box? Annu. Rev. Ecol. Systematics 21:129-166.

King, R.C.(ed.). 1974. Handbook of genetics. vol.2. Plants, plant viruses, and protists. Plenum Press, New York.

Kotilainen, M., Y. Helariutta, M. Mehto, E. Pöllänen, V.A. Albert, P. Elomaa, and T.H. Teeri. 1999. GEG participates in the regulation of cell and organ shape during corolla and carpel development in Gerbera hybrida. Plant Cell 11:1093-1104.

Natarella, N.J. and K.C. Sink. 1971. The morphogenesis of double flowering in Petunia hybrida Hort. J. Amer. Soc. Hort. Sci. 96:600-602.

Nugent, P.E. and R.J. Snyder. 1967. The inheritance of floret doubleness, floret center color, and plant habit in Pelargonium hortorum Bailey. Proc. Amer. Soc. Hort. Sci. 91:680-690.

Raghava, S.P.S. and S.S. Negi. 2001. Inheritance of flower type and doubleness in China aster. J. Ornamental Hort. (New Series) 4:7-12.

Rebhan, J. 1951. Gerberas under glass. Florists' Rev. 108:19-21.

Reynolds, J. and J. Tampion. 1983. Double flowers. Scientific and Academic Editions, New York.

Rogers, M.N. and B.O. Tjia. 1990. Gerbera production for cut flowers and pot plants. Timber Press, Portland, Ore.

Saunders, E.R. 1917. Studies on the inheritance of doubleness in flowers, II. Meconopsis, Althea, and Dianthus. J. Genet. 6:165-184.

Scovel, G., H. Ben-Meir, M. Ovadis, H. Itzhaki, and A. Vainstein. 1998. RAPD and RFLP markers tightly linked to the locus controlling carnation (Dianthus caryophyllus) flower type. Theor. Appl. Genet. 96:117-122

Scutt, C.P., M. Oliveira, P.M. Gilmartin, and I. Negrutiu. 1999. Morphological and molecular analysis of a double-flowered mutant of the dioecious plant white campion showing both meristic and homeotic effects. Dev. Genet. 25:267-279.

Stubbe, H. 1966. Genetik und Zytology von Antirrhinum L. sect. Antirrhinum. Fischer, Jena.

Van der Krol,A.R. and N.-H. Chua. 1993. Flower development in petunia. Plant Cell 5:1195-1203.

Wit, F. 1937. Contributions to the genetics of the china aster. Genetica 19:1-104.

Yu, D., M. Kotilainen, E. Pöllänen, M. Mehto, P. Elomaa, Y. Helariutta, V.A. Albert, and T.H. Teeri. 1999. Organ identity genes and modified patterns of flower development in Gerbera hybrida (Asteraceae). Plant J. 17:51-62. 